\title{
PELATIHAN PENGGUNAAN ANYFLIP UNTUK PENYUSUNAN E-BOOK BAGI GURU MGMP EKONOMI KABUPATEN BANGKALAN
}

\author{
Putri Ulfa Kamalia1), Riza Yonisa Kurniawan'1), Retno Mustika Dewi'), Ni'matush Sholikhah'), \\ Heni Purwa Pamungkas ${ }^{1)}$ \\ 1)Jurusan Pendidikan Ekonomi, Fakultas Ekonomika dan Bisnis, Universitas Negeri Surabaya, Surabaya, \\ Jawa Timur, Indonesia \\ Corresponding author : Putri Ulfa Kamalia \\ E-mail : putrikamalia@unesa.ac.id
}

Diterima 30 Juli 2021, Direvisi 08 Agustus 2021, Disetujui 09 Agustus 2021

\begin{abstract}
ABSTRAK
Pandemi Covid-19 mengakibatkan pembelajaran tingkat pendidikan SMA dilaksanakan dari rumah atau pembelajaran jarak jauh. Berdasarkan analisis survei yang telah dilakukan pada kelompok guru MGMP Ekonomi SMA Kabupaten Bangkalan dapat ditemukan fakta bahwa kurangnya keahlian guru dalam menggunakan teknologi terutama mengembangkan bahan ajar jarak jauh yang dapat membuat suasana belajar menyenangkan dan dapat dipahami oleh peserta didik. Solusi yang dapat dilakukan untuk mengatasi permasalahan tersebut yaitu dengan mengadakan pelatihan penggunaan AnyFlip untuk penyusunan e-book dalam rangka optimalisasi pembelajaran jarak jauh di masa pandemi Covid19. Metode yang dilakukan dibagi menjadi beberapa tahapan yaitu persiapan, sosialisasi, pelaksanaan pelatihan serta pendampingan dan evaluasi. Dari hasil pelaksanaan pelatihan didapatkan bahwa penyusunan e-book berbasis AnyFlip sangat mudah diaplikasikan oleh guru MGMP Ekonomi Kabupaten Bangkalan dengan peserta rata-rata berusia 44 tahun dan rata-rata mengajar selama 17 tahun. Sehingga sebanyak $57,1 \%$ menyatakan sangat setuju dan $42,9 \%$ menyatakan setuju bahwa pelatihan penyusunan e-book AnyFlip dapat meningkatkan pengetahuan serta keterampilan para guru dalam menyusun bahan ajar berbasis teknologi agar dapat meningkatkan hasil belajar peserta didik. Peserta pelatihan yaitu guru MGMP Ekonomi Bangkalan mengharapkan adanya pelatihan lanjutan yang berkesinambungan seperti pelatihan media pembelajaran interaktif agar dapat meningkatkan minat belajar peserta didik. Sehingga dengan adanya pelatihan akan meningkatkan soft skill para guru.
\end{abstract}

Kata kunci: anyFlip; e-book; MGMP ekonomi kabupaten Bangkalan; pelatihan

\begin{abstract}
The Covid-19 pandemic has resulted in high school education level learning being carried out from home or distance learning. Based on the survey analysis that has been conducted on the MGMP Economics teacher at Bangkalan High School, it can be found that there is a lack of teacher expertise in using technology, especially developing distance teaching materials that can make the learning atmosphere fun and understandable by students. The solution that can be offered to overcome these problems is by holding training on the use of AnyFlip for the preparation of e-books in the context of optimizing distance learning during the Covid-19 pandemic. The method is carried out in several stages, namely preparation, socialization, implementation of training as well as evaluation and monitoring. From the results of the training, it was found that the preparation of the AnyFlip-based e-book was very easy to apply by the MGMP Economics teacher at Bangkalan High School with an average participant of 44 years old and an average of 17 years of teaching. So as many as $57.1 \%$ strongly agree and $42.9 \%$ agree that the AnyFlip e-book preparation training can improve the knowledge and skills of participants in compiling technology-based teaching materials which are later expected to improve student learning outcomes. The training participants, namely the Bangkalan Economics MGMP teacher, hoped that there would be continuous follow-up training such as interactive learning media training to increase students' interest in learning. So that with the training, it will improve the soft skills of teachers.
\end{abstract}

Keywords: anyFlip; e-book; economics teacher at Bangkalan high school; training

\section{PENDAHULUAN}

Kemajuan suatu bangsa dapat diukur

melalui pendidikan yang merupakan investasi jangka panjang. Banyak sekali faktor yang dapat mempengaruhi keberhasilan pendidikan, namun beberapa diantaranya adalah ketersediaan sarana prasana serta kompetensi yang dimiliki oleh pendidik. Akan tetapi, pada 
Tahun 2020 pendidikan di Indonesia mengalami revolusi akibat adanya pandemi Covid-19. Sektor pendidikan di Negara Indonesia mengalami perubahan besar akibat adanya penyebaran virus Covid-19 yang mengakibatkan kurang lebih 45 juta peserta didik tidak dapat melakukan pembelajaran secara langsung(Azzahra, 2020). Semua pembelajaran baik di tingkat pendidikan SMA bahkan perguruan tinggi dilaksanakan dari rumah atau pembelajaran jarak jauh. Hal ini dilakukan untuk mencegah penularan virus Covid-19 sesuai dengan yang tertuang pada Surat Edaran yang diterbitkan oleh Mendikbud Nomor 3 Tahun 2020 mengenai pencegahan Covid-19 pada Satuan Pendidikan.

Pada pelaksanaan pembelajaran jarak jauh atau yang biasa dikenal dengan pembelajaran daring (dalam jaringan), pendidik harus memiliki literasi dalam memanfaatkan teknologi yang akan menjadi kunci keberhasilannya. Hal ini disebabkan pembelajaran daring dilakukan dengan media teknologi yang ada. Segala hal yang berkaitan dengan pengetahuan ataupun keterampilan teknologi dimulai dari mengenal, mengaplikasikan, mengolah serta mengkomunikasikan ke dalam sistem informasi disebut literasi teknologi informasi dan komunikasi(Abdul Latip, 2020). Sehingga para pendidik diharapkan memiliki kemampuan mumpuni yang berkaitan dengan literasi teknologi dan komunikasi. Hal ini akan menjadi suatu tantangan besar bagi para pendidik karena selama ini mereka telah terbiasa dengan pembelajaran manual yaitu pembelajaran secara langsung atau tatap muka. Para pendidik diharapkan dapat melakukan pembelajaran secara menyenangkan dan mudah dipahami oleh peserta didik meskipun terdapat sekat berupa jarak. Hal ini sesuai dengan Surat Edaran yang diterbitkan Mendikbud Nomor 36926/MPK.A/HK/2020 tentang pembelajaran daring mengenai proses pembelajaran yang menyenangkan bagi peserta didik oleh para pendidik. Sehingga diperlukan suatu terobosan inovasi dan kreatifitas dalam menyiapkan perangkat pembelajaran secara daring.

Pembelajaran jarak jauh sangatlah memberikan tantangan bagi para pendidik dikarenakan selama ini mereka telah terbiasa dengan pembelajaran tatap muka, dimana terdapat interaksi secara langsung dengan peserta didik. Perhatian, pengalaman, percaya diri yang dimiliki oleh pendidik, kreatifitas dalam menggunakan media serta dapat menjalin komunikasi yang baik dengan peserta didik walaupun secara daring merupakan beberapa faktor yang penting agar menciptakan sistem pembelajaran jarak jauh yang optimal(Prawiyogi, Anggi Giri, 2020). Pada implementasinya, hingga saat ini pembelajaran jarak jauh masih mengalami banyak hambatan seperti sinyal internet yang buruk dan tidak merata di setiap daerah, sarana dan prasarana yang kurang memadai serta masih rendahnya motivasi untuk meningkatkan keberhasilan pembelajaran jarak jauh(Sari et al., 2020). Hal ini disebabkan karena perkembangan teknologi yang terjadi begitu cepat dan sebagian besar pendidik belum siap untuk menggunakannya.

Berdasarkan analisis survei yang telah dilakukan pada kelompok guru MGMP Ekonomi SMA Kabupaten Bangkalan dapat ditemukan fakta bahwa para guru kesulitan dalam mengimplementasikan pembelajaran jarak jauh yang menyenangkan. Permasalahan yang terjadi adalah kurangnya keahlian para guru dalam menggunakan teknologi serta belum cukup mampu untuk mengembangkan bahan ajar jarak jauh yang dapat membuat suasana belajar menyenangkan sehingga peserta didik dapat memahami materi yang disampaikan.

Salah satu hal yang diperlukan untuk menunjang proses pembelajaran jarak jauh adalah pemilihan bahan ajar yang tepat. Bahan ajar merupakan suatu bahan atau materi dalam perangkat pembelajaran yang dibuat secara rinci dan sistematis agar peserta didik lebih mudah dalam memahami pelajaran yang diikuti dan juga pendidik dapat lebih mudah untuk mengimplementasikan kompetensi yang dimiliki(Andi, 2011). Pembelajaran pada Kurikulum 2013 tingkat SMA dituntut untuk menggunakan pendekatan saintifik(Ulandari et al., 2018). Pembelajaran dalam Kurikulum 2013 menekankan sistem pembelajaran yang berorientasi pada peserta didik, sedangkan guru hanya sebagai fasilitator. Sehingga ketika pembelajaran terpusat pada peserta didik, maka diperlukan suatu bahan ajar yang dapat menumbuhkan keaktifan ataupun respon positif bersifat kritis bagi peserta didik. Menurut penelitian yang dilakukan oleh(Wahyuni, 2015), salah satu cara untuk meningkatkan berpikir kritis bagi peserta didik adalah dengan mengembangkan bahan ajar yang akan disampaikan secara kreatif dan inovatif. Implementasi pembelajaran menggunakan pendekatan saintifik juga telah terbukti berpengaruh signifikan terhadap hasil belajar dan kemampuan berpikir kritis peserta $\operatorname{didik(Asta~et~al.,~2015).~}$

Selain itu, menurut(Hasan, 2018) untuk mengatasi hambatan agar peserta didik dapat mempelajari materi dalam waktu singkat, maka diperlukan pengembangan bahan ajar berupa e-book interaktif dengan pendekatan saintifik berbasis LCDS untuk menumbuhkan 
kemampuan berpikir kritis pada peserta didik. Berdasarkan penelitian(Raihan, 2021), efektivitas e-book lesson plan berbasis hypercontent yang dilaksanakan dalam kegiatan workshop blended learning dapat disimpulkan bahwa kualitas RPP guru meningkat apabila dibandingkan sebelum pelaksanaan workshop (pretest) daripada sesudah pelaksanaan workshop (posttest). Sehingga, penggunaan e-book lesson terbukti efektif dalam meningkatkan kemampuan guru untuk mengembangkan perangkat pembelajaran dengan pendekatan saintifik. Hal ini sejalan dengan penelitian(Rohayati, 2019) yakni dalam kegiatan pembelajaran pada mata pelajaran administrasi pajak dinilai sangat baik ketika menggunakan media $e$-book berbasis android dengan pendekatan saintifik. Selain itu, berdasarkan penyajian, komponen isi, bahasa, serta kegrafikan terhadap bahan ajar e-book interaktif mendapatkan respon peserta didik yang sangat baik dengan persentase rata-rata sebesar 94,08\%(Dewi \& Rohayati, 2012).

Sehingga pada saat pandemi berlangsung seperti saat ini, semua guru dituntut untuk melakukan pembelajaran jarak jauh yang menyenangkan bagi peserta didik. Para guru harus kreatif dan inovatif dalam mengembangkan bahan ajar berbasis teknologi, salah satunya yaitu dengan penyusunan e-book AnyFlip. AnyFlip merupakan sebuah aplikasi berbasis web yang dirancang untuk membantu para guru membuat animasi e-book yang sesuai untuk media desktop dan mobile sehingga dapat membantu guru dalam menyampaikan materi pembelajaran yang menarik bagi peserta didik di setiap kesempatan(Handayati, 2020). Dengan demikian, diperlukan adanya peningkatan kompetensi guru melalui pengembangan bahan ajar jarak jauh berupa e-book AnyFlip.

Dengan adanya pelatihan penggunaan AnyFlip diharapkan nantinya akan membantu guru-guru MGMP (Musyawarah Guru Mata Pelajaran) Ekonomi SMA Kabupaten Bangkalan dalam melaksanakan pembelajaran jarak jauh dan dapat meningkatkan kompetensi yang dimiliki oleh para tenaga pendidik di masa pandemi Covid-19.

\section{METODE}

Metode pelaksanaan yang kami laksanakan untuk menyelesaikan permasalahan yang dialami guru MGMP Ekonomi SMA Kabupaten Bangkalan telah didiskusikan bersama tim Pengabdian Kepada Masyarakat (PKM) dan dibagi menjadi beberapa tahapan.

Tahap pertama yaitu tahap persiapan.Mitra pengabdian yaitu guru MGMP
(Musyawarah Guru Mata Pelajaran) Ekonomi SMA Kabupaten Bangkalan yang berjumlah 21 orang. Selanjutnya Pada tahap ini, tim PKM mensurvei mitra sasaran yaitu guru MGMP Ekonomi Kabupaten Bangkalan. Kemudian dari hasil analisis survei yang didapat, diidentifikasi masalah yang terjadi. Selanjutnya Tim PKM mendiskusikan solusi yang ditawarkan dari permasalahan yang ada. Pada tahap ini tim PKM juga mempersiapkan materi pelatihan.

Tahap kedua yaitu tahap sosialisasi. Pada tahap ini, tim PKM mensosialisasikan kepada mitra pengabdian yaitu guru MGMP Ekonomi Kabupaten Bangkalan bahwa akan diadakannya pelatihan. Pelatihan dilakukan secara daring (dalam jaringan) melalui Zoom Meeting karena kondisi yang belum memungkinkan untuk melakukan pelatihan secara langsung.

Tahap ketiga yaitu tahap pelatihan. Tim PKM melaksanakan pelatihan secara online kepada mitra pengabdian yaitu guru MGMP Ekonomi Kabupaten Bangkalan.

Tahap keempat yaitu tahap pendampingan dan evaluasi. PKM ini tidak berhenti pada pelatihan saja, akan tetapi juga diadakan pendampingan dan evaluasi bagi guru-guru MGMP Ekonomi Kabupaten Bangkalan yang mengikuti pelatihan.

\section{HASIL DAN PEMBAHASAN \\ Tahapan pertama yaitu persiapan.}

Pada tahap persiapan, tim PKM telah menyebarkan kuesioner mengenai permasalahan pembelajaran jarak jauh terhadap mitra sasaran sasaran yaitu guru MGMP Ekonomi Kabupaten Bangkalan. Solusi yang dapat ditawarkan untuk mengatasi permasalahan-permasalahan yang dialami oleh guru MGMP Ekonomi SMA Kabupaten Bangkalan adalah dengan mengadakan pelatihan penggunaan AnyFlip untuk penyusunan e-book dalam rangka optimalisasi pembelajaran jarak jauh di masa pandemi Covid-19. Pada tahap ini, tim PKM juga telah menyiapkan materi yang akan disampaikan. Materi pertama yaitu teori mengenai bahan ajar. Materi kedua yaitu pengenalan teori mengenai AnyFlip. Kemudian, untuk materi ketiga yaitu mengenai tutorial penggunaan aplikasi AnyFlip untuk penyusunan e-book.

\section{Tahapan kedua yaitu sosialisasi.}

Pada tahap sosialisasi, tim PKM telah mensosialisasikan pamflet pelatihan kepada guru MGMP Ekonomi Kabupaten Bangkalan melalui WhatsApp grup. Sehingga dengan adanya sosialisasi tersebut, para guru-guru MGMP mengetahui adanya pelaksanaan pelatihan. Kemudian, para guru MGMP dapat 
mendaftar melalui link yang telah diberikan. Adapun pamflet pelatihan dapat dilihat pada Gambar 1.

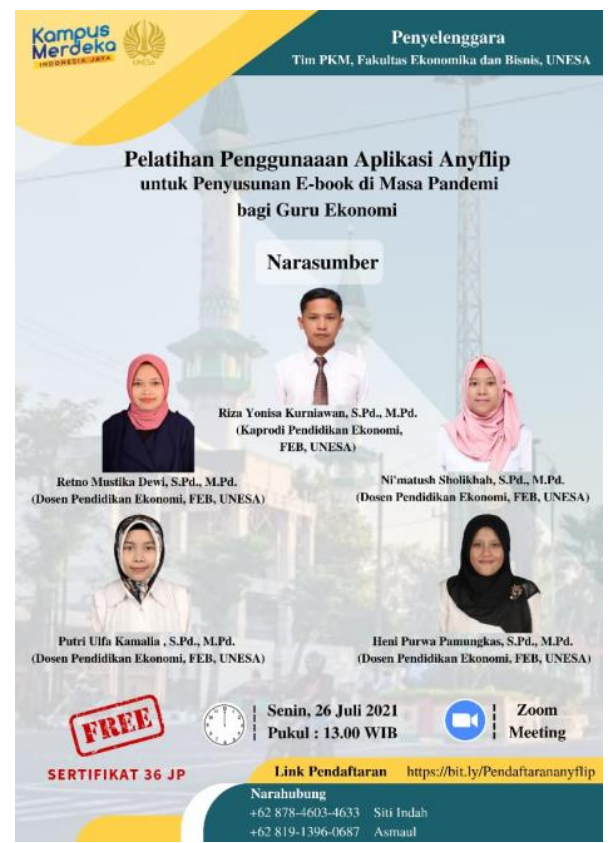

Gambar 1. Pamflet Pelatihan

Tahapan ketiga yaitu pelatihan.

Tim PKM telah melaksanakan pelatihan secara online melalui media Zoom Meeting kepada guru MGMP Ekonomi Kabupaten Bangkalan pada Senin, 26 Juli 2021. Pelatihan diikuti oleh 21 guru anggota MGMP Ekonomi Kabupaten Bangkalan yang dapat dilihat pada Gambar 2.

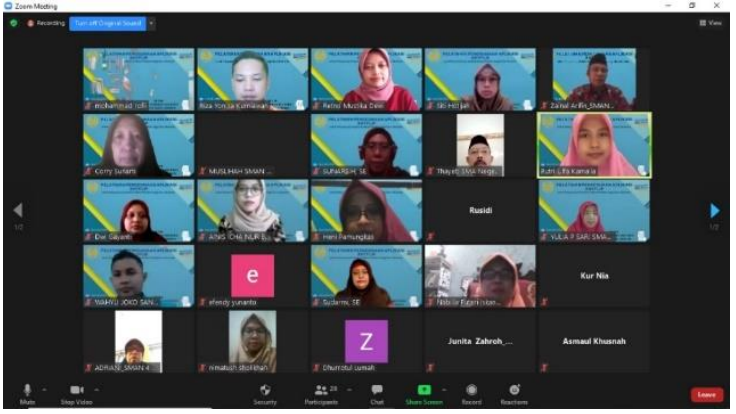

Gambar 2. Pelaksanaan Pelatihan AnyFlip

Materi yang disampaikan dalam pelatihan dibagi menjadi tiga bagian. Materi yang disampaikan pertama yaitu mengenai teori bahan ajar sebagai penyegaran terhadap peserta pelatihan. Kemudian, materi kedua yaitu mengenai pengantar teori AnyFlip yang dapat dilihat pada Gambar 3.

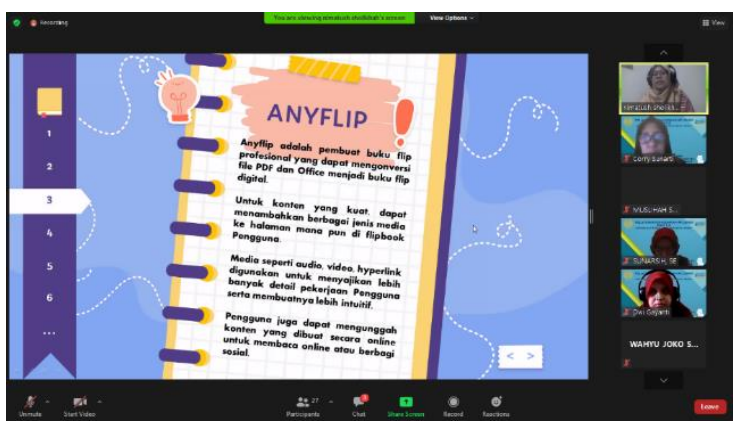

Gambar 3. Sesi Penyampaian Materi Pelatihan

Selanjutnya, yang terakhir diberikan materi mengenai tutorial penggunaan AnyFlip yang dimulai dengan demonstrasi terlebih dahulu kemudian diberikan kesempatan untuk peserta pelatihan mencoba praktik secara langsung yang dipandu oleh pemateri.

\section{Tahap keempat yaitu pendampingan dan evaluasi.}

Setelah melaksanakan pelatihan secara daring melalui Zoom Meeting, diadakan pendampingan dan evaluasi bagi guru-guru MGMP Ekonomi Kabupaten Bangkalan yang mengikuti pelatihan. Setiap peserta dengan rata-rata usia 44 tahun telah berhasil menyusun prototype e-book menggunakan AnyFlip. Sedangkan lama mengajar rata-rata para peserta adalah 17 tahun. Sehingga dengan demikian, penyusunan e-book berbasis AnyFlip sangat mudah diaplikasikan oleh guru berbagai kalangan usia. Hal ini didukung dengan hasil penelitian(Nabilah, n.d.) bahwa handout digital AnyFlip dinyatakan sangat baik digunakan sebagai media pembelajaran yang mudah digunakan dan efisien.

Bagi peserta pelatihan alokasi waktu 2 jam telah memadai dalam memahami penyusunan e-book AnyFlip. Hal ini berdasarkan persentase hasil respon peserta yaitu sebanyak $71,4 \%$ menyatakan sangat setuju dan sebanyak $28,6 \%$ menyatakan setuju apabila alokasi waktu dalam pelaksanaan pelatihan telah mencukupi asalkan pelaksanaan kegiatan pelatihan tepat waktu sesuai dengan susunan acara pelaksanaan. Padahal sebanyak $57,1 \%$ peserta menyatakan peserta belum mengetahui AnyFlip sebelumnya.

Kemudian, materi yang dipaparkan mengenai penyusunan e-book AnyFlip dapat memberikan manfaat bagi peserta karena sebanyak $66,7 \%$ menyatakan setuju dan sebanyak $33,3 \%$ menyatakan sangat setuju bahwa materi yang diberikan pada pelatihan mudah untuk dipraktikkan bagi guru-guru di semua kalangan usia. Sehingga sebanyak $57,1 \%$ menyatakan sangat setuju dan $42,9 \%$ 
menyatakan setuju bahwa kegiatan pelatihan penyusunan e-book AnyFlip dapat meningkatkan pengetahuan serta keterampilan peserta dalam menyusun bahan ajar berbasis teknologi. Hal ini didukung oleh(Widya et al., 2021) bahwa sesuai dengan tuntutan zaman, maka diperlukan penyusunan bahan ajar digital menggunakan AnyFlip yang dapat meningkatkan soft skill guru dalam menyusun bahan ajar yang berkualitas.

Pelatihan penggunaan AnyFlip sangat dibutuhkan sesuai dengan tuntutan zaman. Hal ini disebabkan sebanyak $71,4 \%$ menyatakan penyusunan e-book menggunakan AnyFlip dibutuhkan pada kondisi pandemi seperti saat ini yang mana pembelajaran dilaksanakan secara daring. Diharapkan nantinya ketika para peserta pelatihan telah mempraktikkan e-book AnyFlip dapat meningkatkan hasil belajar para peserta didik sesuai dengan penelitian(Santika \& Sylvia, 2021) bahwa penggunaan e-modul berbasis AnyFlip pada pembelajaran sosiologi SMA kelas X IPS 4 materi nilai dan norma sosial berpengaruh terhadap hasil belajar peserta didik. Hal ini juga didukung oleh penelitian(Martani, 2020) bahwa dengan menerapkan digital book AnyFlip dalam pembelajaran terdapat peningkatan hasil belajar Bahasa Indonesia.

Menurut peserta, keberhasilan pelatihan yang dilaksanakan karena narasumber dapat menjelaskan materi dengan baik. Hal ini karena $57,1 \%$ peserta menyatakan bahwa gaya bahasa yang digunakan narasumber komunikatif dan mudah untuk dimengerti serta narasumber dapat menjawab pertanyaan dengan baik sehingga dapat meningkatkan motivasi peserta untuk membuat bahan ajar yang menarik.

Kemudian berdasarkan survei respon peserta mengharapkan adanya pelatihanpelatihan yang berkesinambungan. Rata-rata para peserta menginginkan adanya pelatihan media pembelajaran interaktif agar dapat meningkatkan minat belajar peserta didik. Dengan adanya pelatihan, maka akan mengembangkan soft skill berbasis teknologi yang dimiliki oleh peserta sebagai tenaga pendidik.

\section{SIMPULAN DAN SARAN}

Penyusunan e-book berbasis AnyFlip sangat mudah diaplikasikan oleh guru MGMP Ekonomi Kabupaten Bangkalan dengan peserta rata-rata berusia 44 tahun dan rata-rata mengajar selama 17 tahun. Sehingga sebanyak $57,1 \%$ menyatakan sangat setuju dan $42,9 \%$ menyatakan setuju bahwa kegiatan pelatihan penyusunan e-book AnyFlip dapat meningkatkan pengetahuan serta keterampilan peserta dalam menyusun bahan ajar berbasis teknologi yang nantinya diharapkan dapat meningkatkan hasil belajar peserta didik.

Peserta pelatihan yaitu guru MGMP Ekonomi Bangkalan mengharapkan adanya pelatihan-pelatihan lanjutan yang berkesinambungan. Rata-rata dari para peserta menginginkan adanya pelatihan media pembelajaran interaktif agar dapat meningkatkan minat belajar peserta didik. Sehingga dengan adanya pelatihan, maka akan meningkatkan soft skill para guru.

\section{DAFTAR RUJUKAN}

Abdul Latip. (2020). PERAN LITERASI TEKNOLOGI INFORMASI DAN KOMUNIKASI PADA PEMBELAJARAN JARAK JAUH DI MASA PANDEMI COVID-19. EduTeach: Jurnal Edukasi Dan Teknologi Pembelajaran, 1(2). https://doi.org/10.37859/eduteach.v1i2.19 56

Andi, P. (2011). Panduan Kreatif Membuat Bahan Ajar Inovatif: Menciptakan Metode Pembelajaran yang Menarik dan Menyenangkan. In Diva Press.

Asta, I. K. R., Agung, A. A. G., \& Widiana, I. W. (2015). Pengaruh Pendekatan Saintifik dan Kemampuan Berpikir Kritis terhadap Hasil Belajar IPA. E-Journal PGSD Universitas Pendidikan Ganesha, 3(1).

Azzahra, N. F. (2020). Mengkaji Hambatan Pembelajaran Jarak Jauh di Indonesia di Masa Pandemi Covid-19. Center for Indonesians Policy Studies, 19(2).

Dewi, D. R., \& Rohayati, S. (2012). Pengembangan Bahan Ajar E-Book Interaktif Materi Jurnal Khusus Akuntansi Perusahaan Dagang Berbasis Scientific Approach Sebagai Sumber Belajar Alternatif Kelas XI SMK Negeri 2 Buduran Sidoarjo. Jurnal Pendidikan Akuntansi, 01(01).

Handayati, S. (2020). PENGEMBANGAN MEDIA PEMBELAJARAN E-BOOK DENGAN MEMANFAATKAN FITUR RUMAH BELAJAR PADA PADA MATA PELAJARAN IPA. JIRA: Jurnal Inovasi Dan Riset Akademik, 1(4). https://doi.org/10.47387/jira.v1i4.61

Hasan, M. F. (2018). Pengembangan E-Book Interaktif dengan Pendekatan Saintifik Berbasis LCDS Pada Materi Sumber Daya Energi untuk Menumbuhkan Kemampuan Berpikir Kritis Pada Peserta didik. Digilib Unila. http://digilib.unila.ac.id/id/eprint/54500

Martani, K. D. (2020). Penerapan Media Pembelajaran Digital Book Menggunakan Aplikasi Anyflip Untuk Meningkatkan 
Kualitas Pembelajaran Bahasa Indonesia Dalam Mengidentifikasi Unsur Intrinsik Cerita Siswa Kelas 4 SD N Bagusan Kecamatan Parakan Kabupaten Temanggung. JP3 (Jurnal Pendidikan Dan Profesi Pendidik), 6(1). https://doi.org/10.26877/JP3.V6l1.7296

Nabilah. (n.d.). PENGEMBANGAN HANDOUT DIGITAL ANYFLIP PADA MATERI MENGANALISIS LIMBAH BUSANA SUB TEMA OUTER ORIGAMI RABBIT ZERO WASTE / Jurnal Tata Busana. Retrieved August 8, 2021, from https://ejournal.unesa.ac.id/index.php/jur nal-tata-busana/article/view/40427

Prawiyogi, Anggi Giri, D. (2020). Efektifitas Pembelajaran Jarak Jauh Terhadap Pembelajaran Peserta didik di SDIT Purwakarta. JPD: Jurnal Pendidikan Dasar.

Raihan, S. (2021). Implementasi Workshop Blended Learning Menggunakan E-Book Lesson Plan Berbasis Hypercontent Dalam Meningkatkan Kompetensi Guru. Jurnal Pendidiikan Publikasi, 11(1).

Rohayati, irma fitriani dan suci. (2019). PENGEMBANGAN E-BOOK BERBASIS ANDROID DENGAN PENDEKATAN SAINTIFIK PADA MATA PELAJARAN ADMINISTRASI PAJAK KELAS XII AKUNTANSI DI SMK NEGERI 2 BUDURAN Irma Fitriani. Jurnal Pendidikan Akuntasi, 7(1).

Santika, A., \& Sylvia, I. (2021). Efektivitas EModul Berbasis Anyflip untuk Meningkatkan Kemampuan Penguasaan Materi Peserta Didik pada Materi Nilai dan Norma Sosial Kelas X di SMA N 3 Payakumbuh. Jurnal Sikola: Jurnal Kajian Pendidikan Dan Pembelajaran, 2(4). https://doi.org/10.24036/sikola.v2i4.128

Sari, W., Rifki, A. M., \& Karmila, M. (2020). Analisis Kebijakan Pendidikan Terkait Implementasi Pembelajaran Jarak Jauh Pada Masa Darurat Covid 19. Jurnal MAPPESONA, 1.

Ulandari, F. S., Wahyuni, S., \& Bachtiar, R. W. (2018). PENGEMBANGAN MODUL BERBASIS SAINTIFIK UNTUK MELATIH KEMAMPUAN BERPIKIR KRITIS PADA MATERI GERAK HARMONIS DI SMAN BALUNG. JURNAL PEMBELAJARAN FISIKA, https://doi.org/10.19184/jpf.v7i1.7220

Wahyuni, S. (2015). Pengembangan Bahan Ajar IPA Untuk Meningkatkan Kemampuan Berpikir Kritis Siswa SMP. PROSIDING: Seminar Nasional Fisika Dan Pendidikan Fisika, 6(6), 2015. https://jurnal.fkip.uns.ac.id/index.php/pros fis $1 /$ article/view/7857

Widya, W., Zaturrahmi, Z., Muliani, D. E., Indrawati, E. S., Yusmanila, Y., \& Nurpatri, Y. (2021). PELATIHAN PEMBUATAN BAHAN AJAR DIGITAL MENGGUNAKAN APLIKASI KVSOFT FLIPBOOK DAN WEB ANYFLIP DI SMP NEGERI 41 PADANG. Jurnal Pengabdian Masyarakat Multidisiplin, 4(3), 183-189. https://doi.org/10.36341/JPM.V4I3.1865 